\title{
Improvement of Orchid Vanda Hybrid (Vanda limbata Blume X Vanda tricolor Lindl. var. suavis) By Colchicines Treatment In Vitro
}

\author{
Mustika Tuwo $^{1} \&$ Ari Indrianto ${ }^{2}$ \\ ${ }^{1}$ Master Program of Biology Faculty, Gadjah Mada University, Yogyakarta, Indonesia \\ ${ }^{2}$ Department of Biology, Faculty of Biology, Gadjah Mada University, Yogyakarta, Indonesia \\ Correspondence: Mustika Tuwo, Master Program of Biology Faculty, Gadjah Mada University, Yogyakarta, \\ Indonesia. Tel: 628-529-985-2835. E-mail: mustikamukti@yahoo.co.id
}

Received: May 27, 2016

Accepted: June 24, 2016

Online Published: July 29, 2016

doi:10.5539/mas.v10n11p83

URL: http://dx.doi.org/10.5539/mas.v10n11p83

\begin{abstract}
The purpose of this research was to evaluate the growth phase of orchid Vanda hybrid (Vanda limbata Blume X Vanda tricolor Lindl. var. suavis) response with colchicines treatment, to determine precise effective concentration of colchicines and duration of treatment to induce polyploidy. This research used variation of colchicines concentration which were $0.01 \% ; 0.05 \% ; 0.1 \% ; 0.5 \% ; 1 \%$ and $0 \%$ and incubation for 6 hours; 12 hours; 18 hours; 24 hours; and 4 days. Treatment was done in aseptic condition using protocorm aged 7 week after sowing. After treatments, plants were planted on Vacint and Went (VW) medium supplemented with of 150 $\mathrm{ml} / \mathrm{l}$ coconut water. After four months, plants were subcultured in medium $\mathrm{VW}+150 \mathrm{ml} / \mathrm{l}+150 \mathrm{~g} / \mathrm{l}$ banana extract. The results showed that the orchid Vanda hybrid was intolerant to colchicine concentration of $0.1 ; 0.5$ and $1 \%$ by death protocorm was more than $50 \%$. Concentration of $0,5 \%$ with 6 hours soaking time is the most effective to induced tetraploid in orchid Vanda hybrid. Morphological characters of tetraploid plantlets had lower average number and length of roots, number, length, and width of leaves than those of control. Anatomical characters of tetraploid plantlets revealed the highest stomatal size and had smaller of stomatal index than controls. This evident indicated a negative correlation between stomatal index and ploidy level. Cytological analysis with flow cytometry revealed that tetraploid plantlets $(2 \mathrm{n}=4 \mathrm{x}=76)$ stained with DAPI showed the chromosome number more than those of control $(2 n=2 x=38)$.
\end{abstract}

Keywords: polyploidization, colchicine, vanda orchid, chromosome number

\section{Introduction}

Indonesia is a country that is very rich in diversity of species and varieties of various horticultural crops, one of them is orchid. Of the 20,000 species of orchids in the world, Indonesia has about 5000 species of wild orchids (Irawati, 2002; Schuiteman, 2010). The types of orchids that have been received in the international market, among others Dendrobium, Arachis, Cymbidium, Phalaeonopsis, Vanda, and Oncidium (Nurmalinda et al., 1999). Vanda limbata Blume and Vanda tricolor Lindl. var. suavis is a local orchid of Indonesia which has a superior characters as the parent crosses, so expect through crossbreeding both local Indonesian orchid species will be produced orchid hybrids that have diverse properties because it comes from a different species. Quality improvement of orchid can be achieved by genetic improvement through crossing, while quantity improvement can be done by propagation through in vitro culture, number of seedlings obtained more in a relatively short time.

Development of orchids can be done through mutation and transgenic. Genetic mutations are increasingly being used to produce new varieties with physical characteristics and particular phenotypes, such as changes in growth, flower color, increase in size and adaptability. One of mutation techniques can be applied to plants is a chemical mutation using colchicine compound. Treatment with colchicine mutation would cause a duplication of chromosomes (polyploidization) followed by an increase in the size of the cells and tissues of plants. Polyploid orchids generally showed more characteristics compared to its diploid type. Some of the characters are related with polyploidy is an increase in vigor and plant resistance to pests and diseases, the size of the larger flowers and flower colors are more vivid, and the vitality of flowers longer than the type diploid (Zainuddin, 2006; Silalahi, 2011). The method used in this research is explant immersion technique is protocorm in a solution of 
colchicine that has been dissolved in a liquid medium. Various of concentration and length of immersion was conducted to determine the optimum concentration and soaking time that can produce the highest percentage of cells undergoing changes become polyploid.

\section{Materials and Methods}

Materials used in this research were protocorm aged 7 Weeks After Sowing derived from F1 seed germination from crossing of Vanda limbata Blume X Vanda tricolor Lindl. var. suavis on medium Vacint and Went (VW) containing $150 \mathrm{ml} / \mathrm{L}$ of coconut water.

\subsection{Colchicine Treatment}

Protocorm were treated at a concentration of $0.01 ; 0.05 ; 0.1 ; 0.5 ; 1 \%$ with long time $6,12,18,24$ hours and 4 days. Control plants soaked in a VW liquid medium without colchicines. Soaking stopped when compliance with the time variation of each treatment and washed with distilled water three times and placed in a petri dish which was covered with filter paper, waiting for it to dry before planting again to VW solid medium. The cultures were maintained under continuous white light at of $25^{\circ} \mathrm{C}$.

\subsection{Plant Regeneration}

After the colchicine treatment, explants were grown on VW solid medium enriched $150 \mathrm{ml} / \mathrm{L}$ of coconut water. After two months, protocorms were subcultured on medium protokorm VW + coconut water $150 \mathrm{ml} / 1+$ banana extract $150 \mathrm{~g} / 1$ for 4 months.

\subsection{Evaluation of Stomata Size, Stomata Index and Morphology}

Anatomical analysis done by making preparations in the lower epidermis of leaves using glue ALTECO. Orchid plant leaves are cut with a scalpel as much as a leaf blade and then made pieces rectangles with a size of $\pm 1 \times 1$ $\mathrm{cm}$. Samples were placed on a glass object that has been given glue ALTECO, wait for 30 minutes. Samples removed with tweezers (Andini, 2011). Mixture was observed with a microscope with a magnification of 40X, images taken using opti lab.

\subsection{Determination of Ploidy Level}

\subsubsection{Staining with DAPI (4,6-diamidino-2-phenylindole dihydrochloride)}

Chromosome preparation is done by cutting root tip $\pm 3-4 \mathrm{~mm}$ then inserted into the tube containing carnoys solution and incubated at $4^{0} \mathrm{C}$ for 15 minutes. Samples were washed with $50 \%$ ethanol solution to remove carnoys. Solution of DAPI included $100 \mathrm{~mL}$ and incubated for 15 minutes. The sample is placed on a glass object and then drops of glycerin and covered with a deck glass. Squashing process conducted with the tip of the brush to form a single layer cells. Mixture was observed with inverted microscope and documented through optilab. Slide preparation are stored in boxes and placed at $4^{0} \mathrm{C}$.

\subsubsection{Analysis of Flow Cytometry}

Samples were analyzed is the leaf of orchid Vanda hybrid plantlets \pm 6 months old. Leaves chopped in a petri dish which has been given $1 \mathrm{ml}$ of buffer solution OTTO I ( $0,1 \mathrm{M}$ citric acid monohydrate 4,2 gr, $0,5 \%(\mathrm{v} / \mathrm{v})$ Tween $201 \mathrm{ml}$ ). Sample is filtered using $30 \mu \mathrm{m}$ nylon mesh filter into the eppendorf tube. The filtered solution was incubated \pm 1 minute and centrifuged $5000 \mathrm{rpm}$ for $5 \mathrm{~min}$, the supernatant was discarded and then added solution of OTTO II buffer $(0.4 \mathrm{M} \mathrm{Na} 2 \mathrm{HPO} 4.12 \mathrm{H} 2 \mathrm{O} 28.65 \mathrm{~g})$ to $500 \mathrm{~mL}$. The solution was homogenized and poured into the cuvet. The solution added propidium iodide $100 \mathrm{~mL}$ and $100 \mathrm{~mL}$ RNase. Samples were analyzed by Flow Cy space.

\subsection{Statistical Analysis}

Data were analyzed using analysis of variance (ANOVA). Significant differences among treatments were detected using Duncan's Multiple Range Test (DMRT) at the 0, 01 or 0, 05 level of probability (Gomez \& Gomez, 1995).

\section{Results}

\subsection{Survival Level}

Protocorm tolerance 0.01 to $0.05 \%$ colchicine in the treatment of $6,12,24$ hours, and 4 days with a survival rate above $50 \%$, but treatment 18 hours increased to $0.1 \%$ (Fig. 1). 


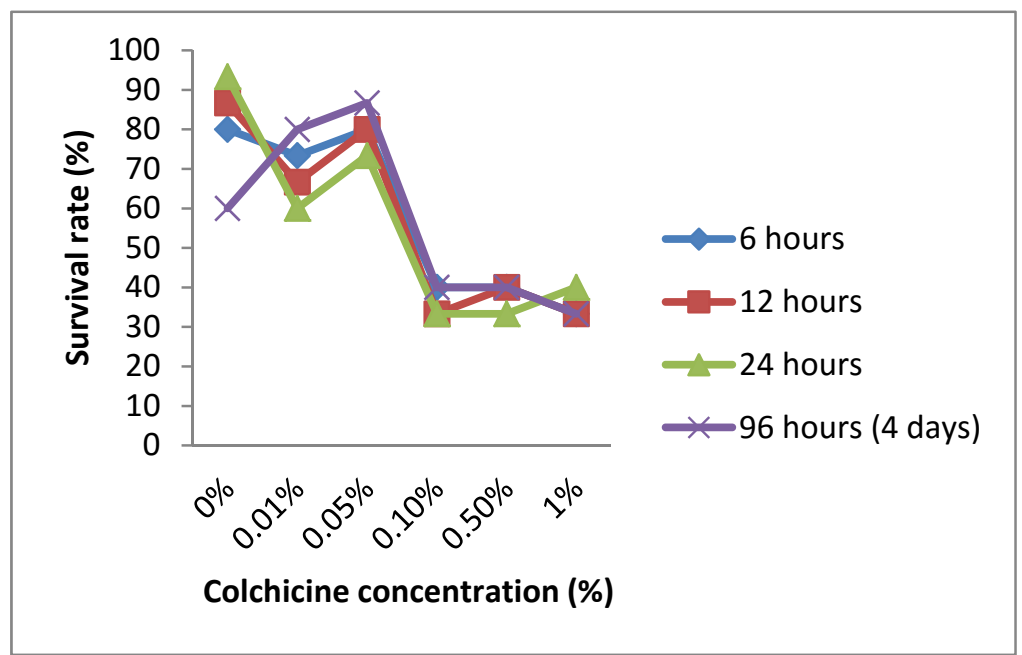

Figure 1. Survival rate of protocorms at various colchicine concentration

\subsection{Morphological Analysis}

Interaction between concentration of colchicines with soaking time significantly affected on morphological characters. Colchicine treatment decreases the amount of root, root length, number of leaves, leaf length and width of leaves. This is shown at the treatment of colchicine concentration of $1 \%$ for 24 hours and 4 days resulted average number of roots as much as 1 less than the controls had a average number of roots 3 (Fig. 2A and $2 \mathrm{~B})$.

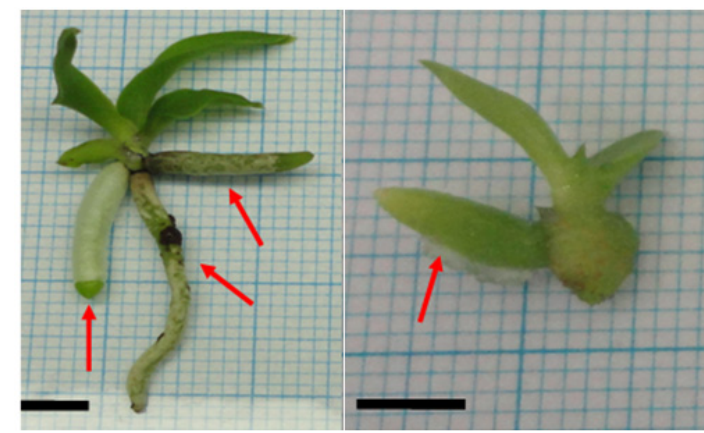

A

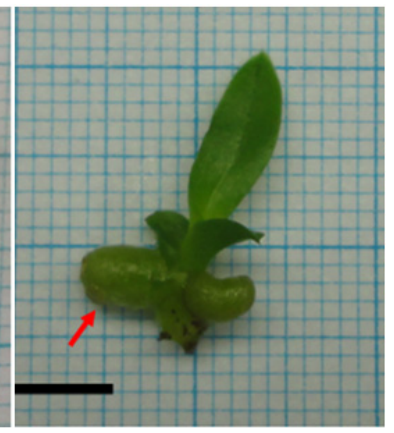

C

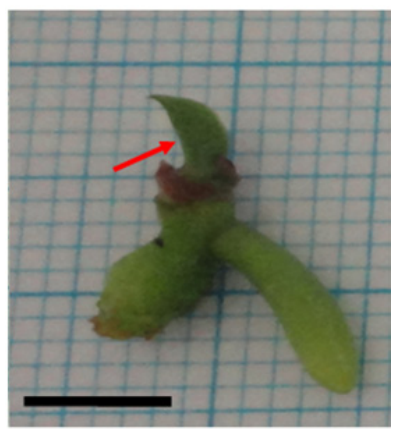

D

Figure 2. Orchid Vanda hybrid \pm 6 months old, A) Control; B) and C) Colchicine $1 \%$ for 4 days

Note. The red arrow show character root changes. Bar: $0,5 \mathrm{~cm}$.

Root length on all variety of concentration and duration of colchicine treatment is smaller than control with a mean length of the roots were $1 \mathrm{~cm}$. The smallest root length was obtained at the concentration of $0.1 \%$ for 4 days, $0.5 \%$ for 12 hours and 4 days and $1 \%$ for 24 hours and 4 days. Root observation in the control and different colchicines treatment, the colchicine treatment have roots that swell and appear thicker and shorter than the size of the control (Fig. 2C). Number of leaves decreased at concentrations of 0.5 and $1 \%$ with 4 day long treatment compared to control as much as one piece with the average number of leaves 4 strands (Fig. 2D).

\subsection{Anatomical Analysis}

The length and width of the highest stomata obtained at a concentration $1 \%$ with long colchicine treatment 24 hours compared with controls. Average length of stomata at $1 \%$ colchicine treatment for 24 hours was $170.32 \mu \mathrm{m}$ and width stomata $118.31 \mu \mathrm{m}$. Stomata length obtained in the control plants was $92.6 \mu \mathrm{m}$ and increased after treated with colchicine $1 \%$ for 24 hours to $170.6 \mu \mathrm{m}$ (Fig. 3A). The width of stomata also increased from 95.8 $\mu \mathrm{m}$ becomes $118.0 \mu \mathrm{m}$ (Fig. 3B). 


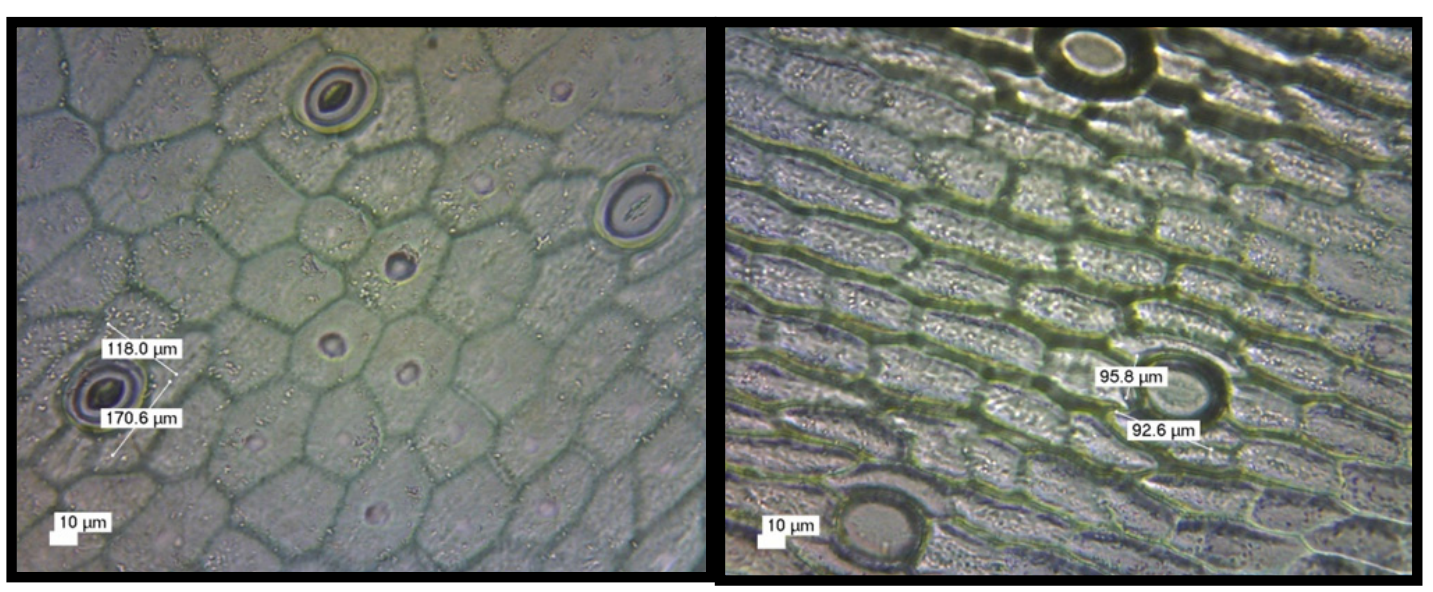

A

B

Figure 3. Effect of colchicines on length and width stomata orchid Vanda hybrid

Note. A. Control; B. Colchicine $1 \%$ for 24 hours

\subsection{Cytological Analysis}

The calculation result of chromosomes by staining with DAPI (4, 6-diamidino-2-phenylindole dihydrochloride) after treatment colchicine concentration of $0.5 \%$ for 18 was 58 . This evident that colchicine successfully induce polyploidisation by folding number of chromosomes (Fig. 4). The number of chromosomes that undergo folding followed by increasing the diameter of the cell nucleus. It looks after colchicine treatment, diameter of the cell nucleus in control plants was $130.1 \mu \mathrm{m}$ increased $162.3 \mu \mathrm{m}$ after treatment colchicine concentration of $0.5 \%$ for 6 hours (Figure 5).

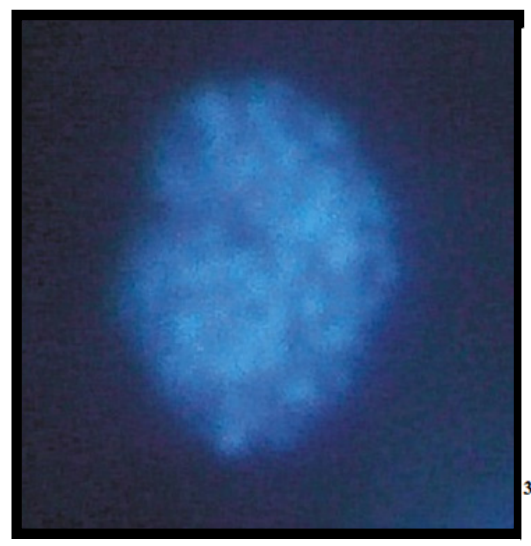

A

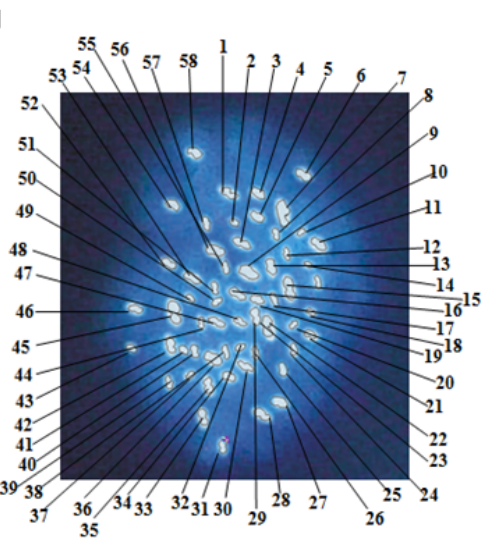

B

Figure 4. Number chromosomes of orchid Vanda hybrid at colchicines $0.5 \%$ for 18 hours

Note. A. Before reconstruction; B. After reconstruction. 


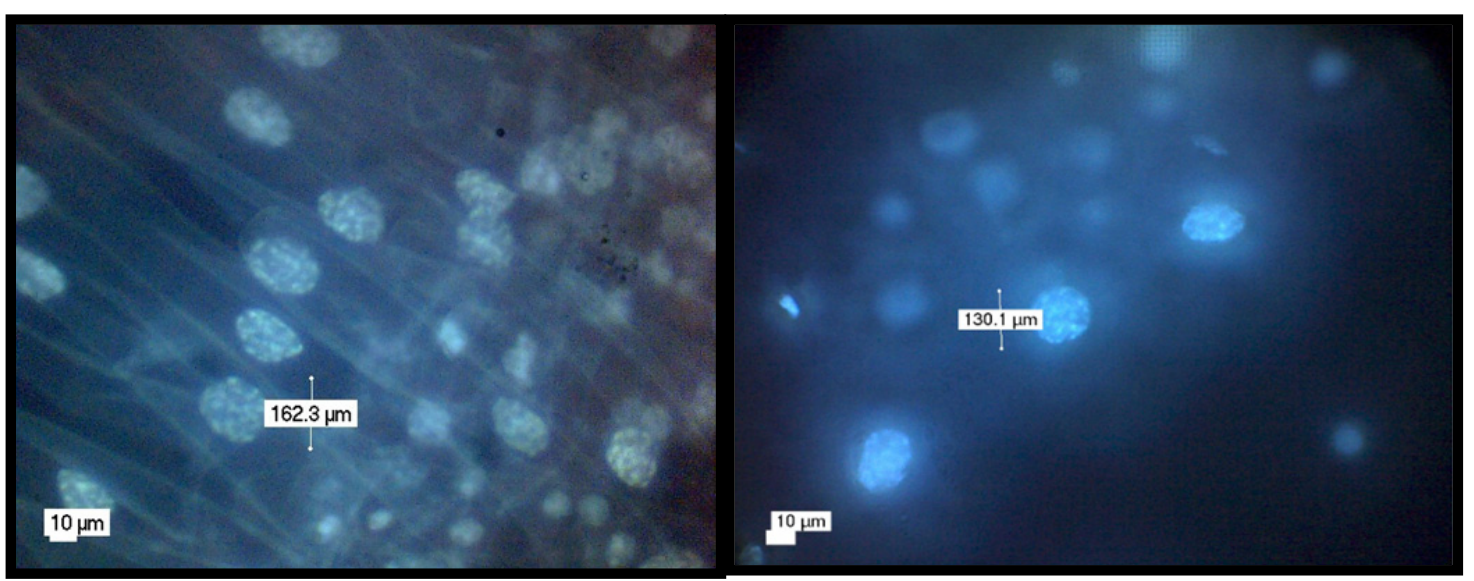

A

B

Figure 5. Diameter of nucleus orchid vanda hybrid

Note. A. Control; B. Colchicine $0.5 \%$ for 6 hours

Cytological analysis followed by flow cytometry also showed that colchicine evidently induce polyploidization on orchid Vanda hybrid. Control plants for ploidy analysis by flow cytometry derived from plantlets \pm 4 months old. Results analysis of control plants presented in the form of DNA G1 peak at channel 200, which is set as standard 2C for diploid cells with a small peak at channel 400 as a characteristic of the peak G2 (Fig. 6A). Treatment colchicine concentration of $0.5 \%$ to 6 hours soaking time produce tetraploid cells with G1 DNA peak at channel 400 and peak G2 at channel 800 (Fig. 6B).

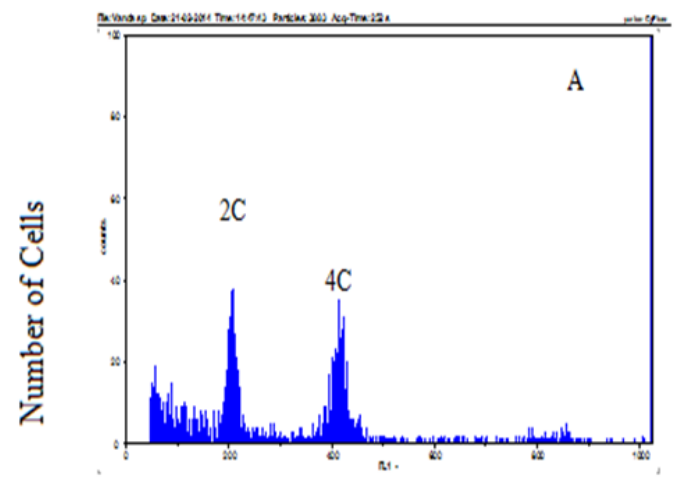

Content of DNA

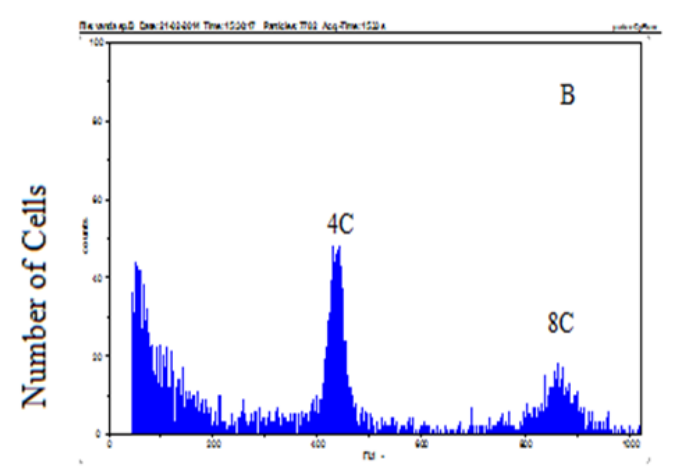

Content of DNA

Figure 6 . Flow cytometry analysis of orchid vanda hybrid

Note. A. Diploid; B. Colchicine $0.5 \%$ for 6 hours

\section{Discussion}

Protocorm resistance level after colchicine treatment depends on the concentration and duration of treatment given. According Atichart \& Bunnag (2007) high concentrations and longer treatment time will decrease the survival rates of explants. Growth phase were treated with colchicine average does not show tolerance at a concentration of 0.1 to $1 \%$. The same is stated by Sarathum et al. (2010), that colchicine concentration of $0.1 \%$ is very toxic for protokorm with the death rate more than $60 \%$. According Atichart (2013), the use of high concentrations colchicine $0.1 ; 0.15$ and $0.2 \%$ with longer treatment more than 24 hours will cause to reduced chlorophyll content and plantlets death after treated with colchicine.

Colchicine treatment at various concentrations showed browning occurs more rapidly than the control that occurs on average in the third week. The possibility as a result of colchicines treatment perceived threats that cause changes in plant physiological and biochemical. Plant reaction to this threat will induce defense 
mechanisms, one of which is to produce phenolic compounds. According to Ebrahim et al. (2011), higher plants have mechanisms to protect themselves from various threats of physical, chemical and biological. This threat will cause to physiological changes in the plants are like strengthening the cell walls through lignifikasi, suberisation, and production of phenolic compounds. As Abdelwahd et al. (2008) states that the phenolic are secondary metabolites regulate plant growth and protect plants from abiotic and biotic stresses. An increase of phenolic compounds in response to the threat of colchicine would cause the accumulation of phenolic causing delays protocorm growth orchid Vanda hybrids.

Colchicine treatment significantly affected number of roots, root length and leaf length, that is high concentration and long treatment decreases the number of roots, root length and leaf length smaller than control. As Chen et al. (2009) stated that plantlets at a lower ploidy levels grew faster and bigger than plantlets which have higher ploidy levels in the same culture period. Oktoploid plant growth is very slow and very small in size compared to plants with low ploidy level.

According Omezzine et al. (2012) identification of polyploid plants can be known through the parameters of morphological, cytological, chemical and physiological. The same is stated by Wongpiyasatid et al. (2005), that length of stomata is an accurate indicator to determine the ploidy levels in some plant species. Size and number of stomata change significantly with the increasing number of chromosomes. Colchicine has been proven as a chemical compound used to induce polyploid on orchids. According to Alberts et al. (2008) colchicine cause depolymerization of microtubules thus inhibiting formation of threads of the spindle and chromosomes do not separate into cell poles at stage of anaphase resulting doubling of chromosome.

\section{Conclusion}

The results showed that the orchid Vanda hybrid was intolerant to colchicine concentration of $0.1,0.5$ and $1 \%$ by death protocorm was more than $50 \%$. Colchicines concentration $0,5 \%$ for 6 hours is the most effective to induced tetraploidization in orchid Vanda hybrid (Vanda limbata Blume $\mathrm{x}$ Vanda tricolor Lindl. var. suavis). Tetraploid plantlets had lower average number and length of roots, number, length, and width of the leaves than those of control. Anatomical characters of tetraploid plantlets revealed the highest stomatal size and had smaller of stomatal index than controls. Cytological analysis with flow cytometry revealed that tetraploid plantlets $(2 \mathrm{n}=4 \mathrm{x}=76)$ stained with DAPI showed the chromosome number more than those of control $(2 \mathrm{n}=2 \mathrm{x}=38)$.

\section{Acknowledgement}

The authors are grateful to Dr.rer.nat Ari Indrianto, Head of Biotechnology Laboratory, Department of Biology, Faculty of Biology, Gadjah Mada University for providing laboratory facilities and Suka Pertiwi for his kind assistance during the research.

\section{References}

Abdelwahd, R., Hakam, N., Labhilili, M., \& Udupa, S. M. (2008). Use of an Adsobent and Antioxidants to Reduce the Effects of Leached Phenolics In Vitro Plantlet Regeneration of Faba Bean L. African Journal of Biotechnology, 7(8), 997-1002.

Alberts, B., Johnson, A., Lewis, J., Raff, M., Roberts, K., \& Walter, P. (2008). Molecular Biology of the Cell (5th Eds.). New York: Garland Science.

Andini, A. N. (2011). Anatomi Jaringan Daun dan Pertumbuhan Tanaman Celosia cristata, Catharanthus roseus, dan Gomphrena globosa pada Lingkungan Udara Tercemar. Bogor. Departemen Biologi FMIPA IPB, Indonesia.

Atichart, P., \& Bunnag, S. (2007). Polyploid Induction in Dendrobium secundum (BI.) Lindl. By in vitro Techniques. Thai Journal of Agricultural Science, 40(1-2), 91-95.

Atichart, P. (2013). Polyploid Induction by Colchicine Treatments and Plant Regeneration of Dendrobium chrysotoxum. Thai Journal of Agricultural Science, 46(1), 59-63.

Chen, W. H., Tang, C. Y., \& Kao, Y. L. (2009). Ploidy Doubling by In Vitro Culture of Excised Protocorms or Protocorm-Like-Bodies in Phalaenopsis Species. Plant Cell Tissue Organ Culture, 98, 229 - 238.

Ebrahim, S., Usha, K., \& Singh, B. (2011). Pathogenitas Related (PR) Protein in Plant Defense Mechanism. Science Againts Microbial Pathogens, 1043-1054.

Gomez, K. A., \& Gomez, A. A. (1984). Statistical Procedures for Agricultural Research.

Irawati (2002). The Conservation of Orchid Species in Indonesia. Indonesian Orchid Seminar, Yogyakarta, Indonesia, October, 20, 2002. 
Nurmalinda, D., Widyastoeti, L., Marpaung, \& Dan, D. M. (1999). Preferensi Konsumen terhadap Bunga Anggrek Potong di Jakarta. Jurnal Hortikultura, 9(2), 146-152 (In Indonesia).

Omezzine, F., Ladhari, A., Nefzi, F., Harrath, R., Aouni, M., \& Haoula, R. (2012). Induction and Flow Cytometry Identification of Mixoploidy through Colchicine Treatment of Trigonella foenum-graecum L. African Journal of Biotechnology, 11, 16434-16442.

Sarathum, S., Hegele, M., Tantiviwat, S., \& Nanakorm, M. (2010). Effect of concentration and duration of Colchicine treatment on polyploidy induction in Dendrobium scabrilingue L. Europ. J. Hort. Sci., 75(3), 123-127.

Schuiteman, A. (2010). Orchid in Indonesia and Their Conservation. Prosiding the 2010 International Seminar on Orchid Coservation and Agribusiness, Yogyakarta, Indonesia, October, 27, 2010.

Silalahi, R. L. W. (2011). Induksi Poliploid pada Anggrek Dendrobium strebloceras dengan Kolkisin. Fakultas Pertanian. Universitas Brawijaya, Malang, Indonesia.

Wongpiyasatid, A., Hormchan, P., Chusreeaeom, K., \& Ratanadilok, N. (2005). Stomatal Size, Stomatal Frequency and Pollen Grain Diameter as Indirect Method for Identification of Ploidy Levels in Cotton. Natural Science, 39, 552-559.

Zainuddin, A. (2006). Optimasi Proses PCR-RAPD Anggrek Phalaeonopsis sp. yang telah diperlakukan dengan Colchicine. Jurusan Agronomi. Fakultas Pertanian. Universitas Muhammadiyah Malang, Indonesia.

\section{Copyrights}

Copyright for this article is retained by the author(s), with first publication rights granted to the journal.

This is an open-access article distributed under the terms and conditions of the Creative Commons Attribution license (http://creativecommons.org/licenses/by/4.0/). 